\title{
How energy efficient is the EEBC? Evaluation based on a simulated office building
}

\author{
R. Emmanuel \& R. Rogithan
}

\begin{abstract}
In this paper, we analyze the recently introduced "Energy Efficient Building Code (EEBC) for Commercial Buildings in Sri Lanka" for its applicability to Sri Lankan office buildings. The focus is on the building envelope and air conditioning requirements of the EEBC and their effect on energy saving. In order to this, we develop a "typical" multi-story office building designed as per the EEBC and simulate its energy and thermal comfort performances using a parametric energy simulation software.
\end{abstract}

The results reveal that the application EEBC to Sri Lankan commercial buildings will actually increase energy consumption over the present scenario. Based on our analysis we recommend a set of improvements to the EEBC in terms of building envelope and set-point temperature requirements.

\section{Introduction}

Sri Lankan architects pay little attention to the energy efficiency aspects of commercial buildings in the present context. Compounding the problem is the lack of detailed guidelines / standards applicable to the Sri Lankan conditions. The recent introduction of an "Energy Efficient Building Code (EEBC) for Commercial Buildings in Sri Lanka" (EEBC, 2000) by the Government of Sri Lanka through the Ceylon Electricity Board (CEB), therefore augurs well for the "Demand Side Management" (DSM) efforts in the country.

The EEBC was introduced by the Government of Sri Lanka in September 2000 for a trial period of three years. During this period, the performance of the EEBC will be monitored and changes, if any, to improve the code may be suggested by energy users. Although compliance with the code is voluntary at present, it may be made compulsory at the end of the review period. At this point, the scope of EEBC may be enlarged to cover other types of buildings as well.

In this study, we simulate the air conditioning load and thermal comfort effects of the EEBC on a "typical" multistorey office building in Colombo to test the efficiency of the code. The "typical" building is specified in terms of wall, roof and window types; window : floor area ratio; floor-to-ceiling height; activity and occupancy level; usage of equipment, etc. Air conditioning (thermostat setting) and the building envelope standards (in terms of the Overall Thermal Transfer Value - OTTV) of the code are analyzed in detail. Based on our results, we suggest some improvements to the code.

\section{Background}

The main type of fuel used in Sri Lanka are bio-mass (including fuel wood, agro-waste), oil (petroleum, crude based) and electricity. However, sustained economic growth and a proliferation of nural electrification programs in recent years have led to a rapid increase in electricity demand in particular. Of this, the electric energy demand by the building sector is considerable.

During the recent past, the demand for electricity rose by $9.5 \%$ per annum. In 1999 , the electricity demand during daytime was $864.5 \mathrm{MW}$ while the nighttime demand was $1291 \mathrm{MW}$. Presently, electricity demand growth rate varies between $8-10 \%$ per annum. It is forecasted that the Sri Lankan electricity demand will quadruple in the next 15years (CEB, 1996).

In 1999, the installed capacity of hydroelectric power plants were $1143 \mathrm{MW}$ and that of thermal plants were $545 \mathrm{MW}$. However, most of the economically viable hydro-electric potential has already been utilized. Moreover, periodic drought's and the changing climatic patterns (cf. Emmanuel, 1999) reduce the reliability of hydro-electric generation. This had led to severe brownouts in 1996 and 2001/2002. In this context, the last few years have seen the country gradually shifting towards thermal power generation. It is estimated that by $2014,82 \%$ of the total electricity demand will be met by thermal power generation (Shrestha and Shrestha 1997). At the same time, the authorities are finding it very difficult to construct thermal power plants in the face of rising opposition from the citizenry on economic and ecological grounds.

Additionally, thermal electricity generation is a highly expensive process, one which the cash-strapped local utility authority (the Ceylon Electricity Board - CEB) can ill-afford: in 1996, the utility company spent about US\$ 1,500 per kVA of thermal power generation (CEB 1996). Thus, economic and political factors make energy conservation an attractive option to the utility company. 


\section{Energy consumption in the commercial sector}

Major sectors of energy consumption of building in Sri Lanka are industrial, household, commercial and others (religious organizations, etc.). Their relative consumption (as a percentage of total energy consumption) is given below (source: CEB, 1996).

$\begin{array}{ll}\text { Industrial } & 41 \% \\ \text { Household } & 32 \% \\ \text { Commercial } & 21 \% \\ \text { Other } & 06 \%\end{array}$

Among these, the rate of increase in energy demand in the commercial sector is the highest due to the rapid development of the sector, changes in life-styles, contemporary architectural practices and lack of suitable energy-saving technologies and building management/automation systems. Due to these reasons, the present annual electricity consumption in commercial buildings, which is approximately 1000 GWh, is expected to increase up to $4350 \mathrm{GWh}$ in 2013. This would form $28 \%$ of the total electricity demand (CEB, 1996).

Most of the energy demand from the commercial building sector comes from lighting and air conditioning. The CEB estimates that in the Sri Lankan commercial building sector, $50-60 \%$ of the total demand is consumed by air-conditioning while $20-30 \%$ is used by the lighting system.

\begin{tabular}{|c|c|}
\hline Air conditioning & \\
\hline Lighting & \\
\hline Otfice equipment & \\
\hline Lifts \& water pumps & \\
\hline Fans & \\
\hline
\end{tabular}

Researchers have estimated that the efficient use of air-conditioning and lighting systems can potentially save around $21-44 \%$ in air conditioning and $21-40 \%$ in lighting (Jeevan.P 1998).

\section{Energy Efficient Building Code for Commercial Buildings (EEBC).}

The importance of the commercial building sector in building-level energy consumption and its potential for rapid growth led the CEB to lobby for the introduction of a design code that stipulates minimum efficiency standards. Such a code - the EEBC - was developed by a World-Bank funded project in 1999/2000 and was introduced in late 2000 for a trial period of three years. The purpose of the EEBC is to encourage energy efficient design of new commercial buildings so that they may be designed, constructed, operated and maintained in a manner that reduces the use of energy without constraining the building function, comfort, or the productivity of the occupants and with appropriate regard for economic considerations.

The scope of the EEBC is limited to new commercial buildings such as offices, hotels, shopping complexes, hospitals and others that are not primarily for residential or industrial use. EEBC stipulates minimum standards for the exterior envelope, systems for ventilation and air-conditioning, electric power and distribution, lighting and service water heating.

The new commercial buildings should follow the EEBC if they exceed any one of the following criteria:

i. Building height exceeding four stories;

ii. Floor area of $2,000 \mathrm{~m}^{2}$ or greater

iii. Building enclosed volume of $5,600 \mathrm{~m}^{3}$ or greater

iv. Electrical peak demand of $100 \mathrm{~kW}$ or greater

v. Air-conditioning cooling capacity of 350 kW (output)

Existing buildings are exempted, as are residential and industrial buildings.

The EEBC deals with five major aspects of buildinglevel energy consumption:
i. Lighting
ii. Ventilation and Air Conditioning
iii. Building Envelope
iv. Electric Power and Distribution
v. Service Water Heating

In this paper, we concentrate on the "Ventilation and Air Conditioning" and the "Building Envelope" aspects of the EEBC. The section below describes the standards stipulated by the EEBC in this regard.

\section{Ventilation \& Air Conditioning}

Calculation Procedures: Cooling system design loads for the purpose of sizing systems and equipment are to be determined in accordance with the procedures described in the latest edition of the ASHRAE Handbook or other equivalent publications.

Indoor Design Conditions: The indoor conditions of an air-conditioned space to be designed for a dry bulb temperature of $24^{\circ} \mathrm{C} \pm 1^{\circ} \mathrm{C}$ and relative humidity of $55 \%$ $\pm 5 \%$. The recommended dry bulb temperature is described as the "Set Point Temperature" in the discussions that follow.

Qutdoor Design Conditions: Dry bulb temperature of $32^{\circ} \mathrm{C}$ and wet bulb temperature of $27^{\circ} \mathrm{C}$. 


\section{Building Envelope}

Solar heat gain through building envelope constitutes a substantial share of the cooling load in a building that will have to be eventually removed by the air-conditioning system at the expense of energy and utility bills. To minimize solar heat gain in a building, the following architectural techniques may be employed: siting and orientation of rectangular buildings to avoid exposure of long axis to east and west, use of light colored exterior wall and roof surfaces, appropriate shading of fenestration, and employing moderate glass window areas. Opaque wall sections and roofs should incorporate thermal insulation materials to minimize heat gains. Air leakage through the building envelope into or from conditioned space should be minimized.

The customary method of specifying the thermal conditions of the building envelope is to indicate its Overall Thermal Transfer Value (OTTV). The implication is that OTTV is proportional to heat gain.

The EEBC specifies that the OTTV for the exterior walls of a Sri Lankan commercial building should not exceed $90 \mathrm{~W} / \mathrm{m}^{2}$. OTTV is a system performance criterion that allows trade-offs among opaque wall and window areas and their thermal and solar characteristics to achieve an overall minimum performance. OTTV is first calculated for each individual façade and then for the building as a whole, taking the weighted average of the individual façade OTTVs.

\section{Method}

In this paper we evaluate the cooling load and thermal comfort performance of a "typical" office building located in the city of Colombo and designed according to the "Ventilation \& Air Conditioning" and the "Building Envelope" requirements of the EEBC. We design the "typical" building according to the EEBC and compare its performance with a building of comparable complexity but designed with a superior (OTTV $=45 \mathrm{~W} / \mathrm{m}^{2}$ ) and an

The hourly variations in internal loads are assumed to be distributed on the basis of the following time inferior (OTTV $=135 \mathrm{~W} / \mathrm{m}^{2}$ ) building envelope as well as a higher indoor set-point temperature $\left(27^{\circ} \mathrm{C}\right)$. Based on the comparisons, a set of guidelines to improve the efficacy of the EEBC are suggested.

In order to define a "typical" office building in Colombo. we carried out a survey of contemporary multi-storey office buildings in the city, whose results are presented in Table 1 below.

Table 1: Parameters of a "typical" Sri Lankan multistory office building

\begin{tabular}{|c|c|}
\hline Parameter & Specification \\
\hline No of floors & 15 \\
\hline Floor-floor height & $3.5 m$ \\
\hline Floor-Ceiling height & $2.5 \mathrm{~m}$ \\
\hline Floor area & $130 \mathrm{~m}^{2}$ ffloor \\
\hline Window area & $130 \mathrm{~m}^{2} /$ floor \\
\hline Ceiling & $\begin{array}{l}10 \mathrm{~mm} \text { thick mineral fiber board on } \\
\text { Aluminum frame }\end{array}$ \\
\hline Glazing & $6 \mathrm{~mm}$ thick tempered glass \\
\hline Floor & $\begin{array}{l}\text { Concrete }(125 \mathrm{~mm})+\text { cement } \\
\text { screed }(50 \mathrm{~mm})+\operatorname{carpet}(12 \mathrm{~mm})\end{array}$ \\
\hline Wall & $\begin{array}{l}\text { Brick }(225 \mathrm{~mm})+\text { plaster }(25 \mathrm{~mm} \\
25 \mathrm{~mm})\end{array}$ \\
\hline Occupants & 75 persons / floor \\
\hline \multicolumn{2}{|l|}{ Internal loads } \\
\hline Lighting & $8000 \mathrm{~W}$ \\
\hline Equipment & $4500 \mathrm{~W}$ \\
\hline Occupants & $\begin{array}{l}5250 \text { W ( } 75 \text { W Per person doing } \\
\text { office work) }\end{array}$ \\
\hline
\end{tabular}

Table 2: Internal load schedule

\begin{tabular}{|lllll|}
\hline Time & Lighting & Equipment & Occupants & Total load \\
\hline $07: 00-08: 00$ & $4000 \mathrm{~W}(50 \%)$ & $1000 \mathrm{~W}(20 \%)$ & $700 \mathrm{~W}(15 \%)$ & $5700 \mathrm{~W}$ \\
\hline $08: 00-17: 00$ & $6000 \mathrm{~W}(75 \%)$ & $4500 \mathrm{~W}(100 \%)$ & $5250 \mathrm{~W}(100 \%)$ & $15750 \mathrm{~W}$ \\
\hline $17: 00-20: 00$ & $5000 \mathrm{~W}(60 \%)$ & $2000 \mathrm{~W}(45 \%)$ & $2100 \mathrm{~W}(40 \%)$ & $9100 \mathrm{~W}$ \\
\hline
\end{tabular}

Note: The percentages in parenthesis indicate the fraction of load assumed to be in actual use.

The analysis is carried out in a typical middle floor $\left(6^{\text {th }}\right.$ floor). The comparisons are made using a parametric energy simulation software (DEROB - LTH). For computer modeling purposes the "typica" building has been simplified into the three occupied volumes and a ceiling volume. All calculations and findings discussed hereafter are of this "typical floor." 


\section{Input data}

Climatic data of Colombo is obtained form of the 30 year average (1969 - 1998) meteorological data. The calculations are made for $15^{\text {th }}$ April, which is typically among the hottest days of the year.

Temperature - Maximum $\left(32.0^{\circ} \mathrm{C}\right)$ \& Minimum $\left(24.8^{\circ} \mathrm{C}\right)$ Humidity - Maximum (90\%) \& Minimum (75\%)

Solar Radiation - Sun Shine Hours (7.9hrs)

\section{Analysis Technique}

The intention of the study is to find out the cooling loads for various conditions. Basically, the cooling temperature and the OTTV of the building are considered as the main variables. Three different models are created with 3 different OTTV values, maintaining the same height and internal conditions (except the set-point temperature) and by changing the other factors like window area, materials of building envelope, orientation, dimensions and window overhangs. The other variable is the internal set-point temperature setting, the three models have been put under temperatures of $24^{\circ} \mathrm{C}$ (which is stipulated in EEBC) and $27^{\circ} \mathrm{C}$ for cooling load calculations.

\section{Results \& Analysis}

In this section, we present the results obtained from computer simulation runs in terms of cooling load and thermal comfort. Cooling load figures (in kWh) are shown for the period of 07:00-20:00 hrs. per

day. It is assumed that the air-conditioning system will not be run during the rest of the day. The thermal comfort conditions are plotted for the same time period and are indicated in terms of the Operative Temperature $\left({ }^{\circ} \mathrm{C}\right)$.

Table 3 indicates the daily cooling load for the cases studied. The case with an OTTV of $90 \mathrm{~W} / \mathrm{m}^{2}$ and a setpoint temperature of $24^{\circ} \mathrm{C}$ will fulfill the EEBC requirements (shown in bold, underlined).

Table 3: Cooling load comparison for a "typical" office bullding

\begin{tabular}{|c|c|c|c|}
\hline \multirow{2}{*}{ Set-point Temperature $\rho$ C $)$} & 45 & 90 & 135 \\
\cline { 2 - 4 } & $45 T\left(W / m^{2}\right)$ \\
\hline 24 & 414.0 & 469.7 & 576.6 \\
\hline 27 & 336.9 & 372.1 & 472.0 \\
\hline
\end{tabular}

Figure 1 shows the thermal comfort comparisons of the three OTTV values considered. Figure 2 indicates the same but for the two set point temperatures.

As can be expected, a lower set-point temperature leads to higher cooling loads and therefore higher energy consumption for space conditioning. It is also clear from the above that lower OTTV lead to lower cooling load. A
Figure 1: Operative Temperature Comparlsons
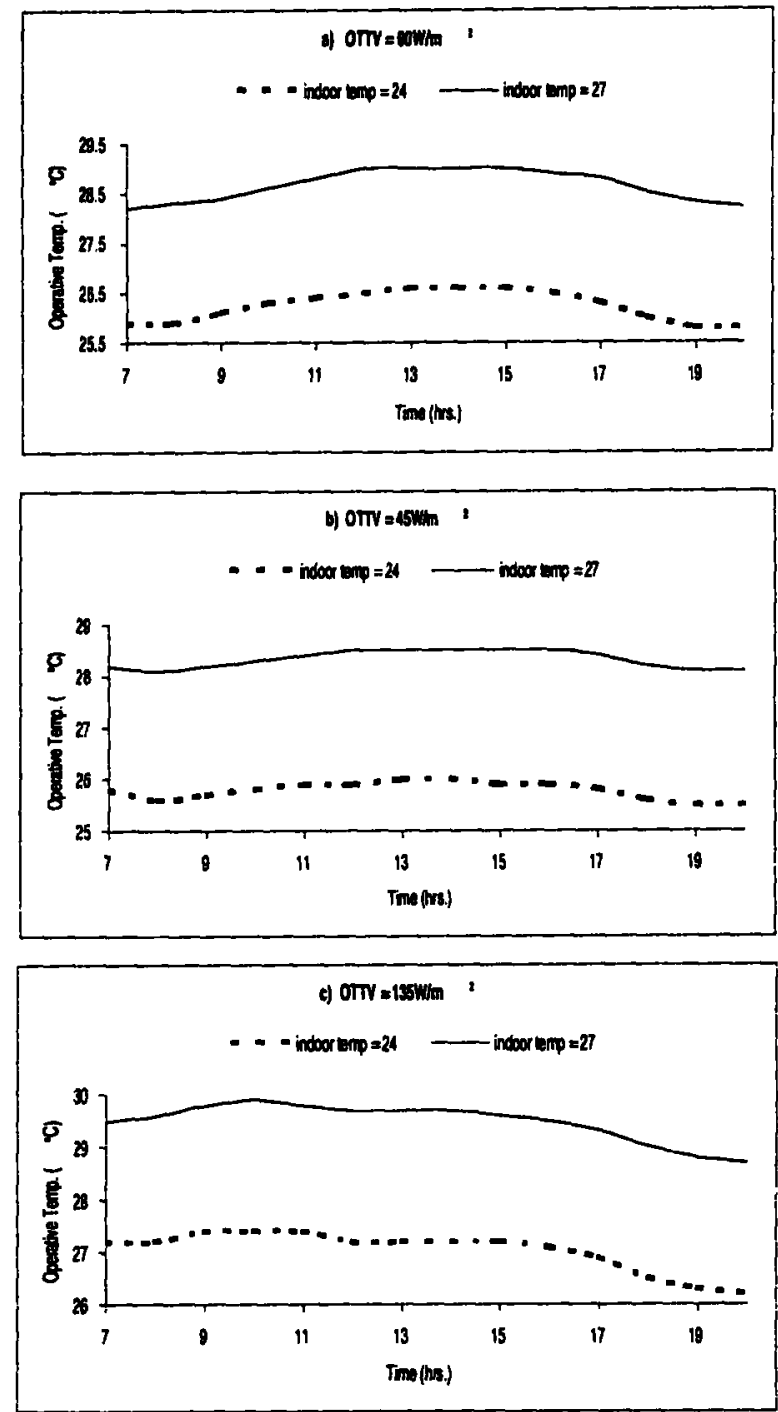

combination of lower OTTV and higher set-point temperature would enable our "typicar" building to consume approximately $28 \%$ less energy than a building that fulfills the EEBC recommendations.

Irespective of the building envelope conditions, a $3^{\circ} \mathrm{C}$ increase in set-point temperature will lead to approximately $18-21 \%$ reduction in the cooling energy requirements of a "typica" commercial building in Colombo. At the same time, an increase in set-point temperature will lead to an operative temperature rise of approximately $2.5^{\circ} \mathrm{C}$, irrespective of the building envelope conditions. In an already stresstul climate such as that of Colombo, such an increase in OT may not be tolerated by all.

On the other hand, manipulating the building envelope conditions provide greater opportunity for energy saving than the mere increase in set-point temperature. While up to $11 \%$ saving in cooling load is possible with an OTTV rectuction from 90 to $45 \mathrm{~W} / \mathrm{m}^{2}$, no discemible drop in thermal comtort (OT differences $\leq 0.5^{\circ} \mathrm{C}$ is detected; see also Figure 2). At the same time an increase in OTTV from 90 to $135 \mathrm{~W} / \mathrm{m}^{2}$ lead to greater increase in OT $\left(07-1.3^{\circ} \mathrm{C}\right)$. Thus, building envelope manipulation could not only result in significant energy savings, they would do so with little or no noticeable drop in thermal discomfort. 
Figure 2: OT Comparisons across set point
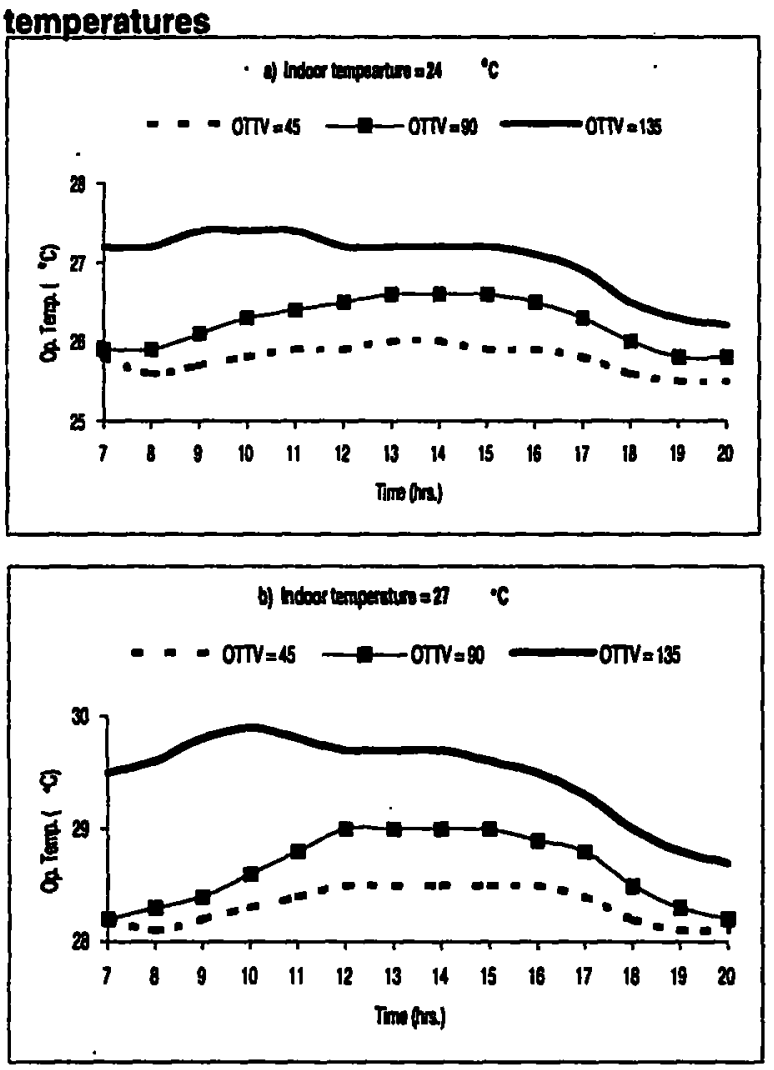

Recommendations to Improve the EEBC

\section{Bullding Envelope Requirements}

The fact that building envelope conditions could be made more thermally conducive in the Sri Lankan context without compromising thermal comfort suggests that the EEBC specifications in terms of OTTV need to be reviewed.

The analysis presented above suggest that reducing the OTTV value to $45 \mathrm{~W} / \mathrm{m}^{2}$ will lead to a minimum of $11 \%$ reduction in cooling load. But the question is, can such reductions be possible in the Sri Lankan context? Our preliminary analysis leads us to answer the question in the affirmative.

The primary determinants of OTTV are, wall type, window type, window area, window orientation and window overhangs. Among these, window area and orientation exert a disproportionate influence on OTTV than the others. By reducing the window area, locating windows predominantly in the north/south walls only, and shading the windows, the OTTV can be significantly reduced. Additionally, better window type (i.e. insulating glass or double glazing) and higher thermal mass in walls could play a role, albeit a small one, in reducing the OTTV. Taking the "typical" building described in Table 1 as an example, Table 4 shows the range of possible OTTV variations in the Sri Lankan context. The OTTV values in each row is calculated keeping all other parameters same as the "typical" building indicated in Table 1.
Table 4: Influence of design optlons on OTTV in the Srl Lankan context

\begin{tabular}{|c|c|}
\hline Design Option & otrv \\
\hline \multicolumn{2}{|l|}{ Walls type } \\
\hline 225 Brick wall w/ plasteir & 90.53 \\
\hline Concrete Masonry Block & 96.86 \\
\hline Reinforced concrete & 108.48 \\
\hline Double leaf brick & 88.63 \\
\hline Aluminum composite panel on brick & 87.15 \\
\hline \multicolumn{2}{|l|}{ Window type } \\
\hline $6 \mathrm{~mm}$ Single glazing & 90.53 \\
\hline Single glazing with curtain & 83.86 \\
\hline Double glazing & 82.90 \\
\hline \multicolumn{2}{|l|}{ Window Area (north/south only) } \\
\hline $26 \%$ of wall area & 62.16 \\
\hline $30 \%$ of wall area & 74.41 \\
\hline $50 \%$ of wall area & 165.0 \\
\hline \multicolumn{2}{|l|}{ Window orientation } \\
\hline All windows on north or south & $57-66$ \\
\hline All windows on east or west & $66-93$ \\
\hline \multicolumn{2}{|l|}{ Window Shading } \\
\hline Windows on north/south walls, no shading & $57-66 \mid$ \\
\hline Same as above, but with $0.75 \mathrm{~m}$ shading & $42-52$ \\
\hline Same as above, but with $1.50 \mathrm{~m}$ shading & $36-42$ \\
\hline Windows on east/west walls, no shading & $66-93$ \\
\hline Same as above, but with $0.75 \mathrm{~m}$ shading & $50-65$ \\
\hline Same as above, but with $1.50 \mathrm{~m}$ shading & $40-54$ \\
\hline
\end{tabular}

The effect of window shading is particularly striking, even when the windows are located on the east/west walls. Even a higher than normal window area, if propenty shaded could easily achieve lower OTTV values without resorting to expensive thermal insulation and/or walls with higher thermal mass. In fact, the manipulation of window parameters is by far the easiest means of achieving thermally significant OTTV reductions in the Sri Lankan context.

In light of the above, it appears that the building envelope requirements of the EEBC is less stringent than what is easily achievable in Sri Lanka. Furthermore, the EEBC is considerably lax than the energy codes 
Built-Environment:Sri Lanka -Vol. 03, Issue 01:2002

applicable in other tropical Asian countries. For example, the Philippines code limits the OTTV at $48 \mathrm{~W} / \mathrm{m}^{2}$ (Rogithan, 2001); Malaysia - $45 \mathrm{~W} / \mathrm{m}^{2}$ (Guidelines for ... ., 1989); Hong Kong $-35 \mathrm{~W} / \mathrm{m}^{2}$ (Towers) and 80 $\mathrm{W} / \mathrm{m}^{2}$ (Podium) (Code of Practice, 1995); Singapore $35 \mathrm{~W} / \mathrm{m}^{2}$ (CP24:Part 2, 1983). The current EEBC requirements are so lenient that almost all contemporary buildings will pass the muster without any additional effort.

\section{Set Point Temperature}

Attempts at quantifying thermal cornfort in the hot-humid region began in the 1940s (Rivera de Figueroa, 1980). These include Ellis $(1952,1953)$ who recorded "comfort" (or neutral) temperature to be $26.1-26.7^{\circ} \mathrm{C}\left(79-80^{\circ} \mathrm{F}\right.$ ) in Singapore, Webb (1959) recording a comfort temperature of $27.2^{\circ} \mathrm{C}\left(\left(81^{\circ} \mathrm{F}\right)\right.$ also in Singapore, Rao (1952) in Calcutta $\left(26.0^{\circ} \mathrm{C}\left[78.8^{\circ} \mathrm{F}\right]\right)$, and Nicol (1974) recording $31.1^{\circ} \mathrm{C}\left(88^{\circ} \mathrm{F}\right)$ in Roorkee, India. In addition, many qualitative descriptive studies on thermal comfort in the hot-humid regions were also carried out. These include Ambler (1955), Ballantyne, et al., (1967) in Port Morsby, Papua New Guinea and Wyndham (1963) in Tropical Australia.

Current thermal comfort practice in the region usually follows the more frequently used temperate climate thermal comfort standards. However, there is evidence that outdoor climate heavily influences human therma comfort indoors, particularly in the tropics. In fact, the strongest evidence for adaptation to the outside conditions or acclimatization related to thermal comfort has come from the hot-humid areas. These studies seem to indicate that thermal comfort of those living in a hothumid environment has closer ties to their previous climatic experiences. To paraphrase Prins (1992), people in the hot-humid zone seems to put their minds and bodies to adapt to heat.

Auliciems (1983) and Humphreys (1981), having analyzed over 50 thermal comfort studies utilizing over 250,000 subjects, found strong correlation between the reported comfort temperatures of these studies and the outdoor temperatures under which they were conducted. Auliciems in particular found the following linear relationship suggesting that the preferred temperature of human beings is directly related to outdoor conditions:

$$
\mathrm{T}_{n}=63.7+0.31\left(\mathrm{~T}_{0}-32\right)\left({ }^{\circ} \mathrm{F}\right)
$$

where $T_{n}$ is thermal neutrality temperature and $T_{0}$ is the outdoor monthly average air temperature.

Considering the fact that outdoor conditions in Sri Lanka typically remain at about $32^{\circ} \mathrm{C}$ during the hot months, the above equation would imply that a thermal neutrality temperature of $27.6^{\circ} \mathrm{C}$ may be acceptable here.
It therefore seems reasonable to suggest that the setpoint temperature in the EEBC be raised up to $27^{\circ} \mathrm{C}$. Up to $20 \%$ cooling energy savings may be realized by such an action.

\section{Conclusion}

The main findings of the present study may be summarized as follows:

1. Maintaining of the upper limit of OTTV to $90 \mathrm{~W} /$ $\mathrm{m}^{2}$ (as suggested in EEBC) is more energy consuming.

2. Reducing a building's OTTV through architectural means is practically possible without incurring much expenditure.

3. Approximately $20 \%$ of air conditioning energy use could be saved by increasing the set point temperature from $24^{\circ} \mathrm{C}-27^{\circ} \mathrm{C}$.

Based on these findings we recommend that the upper limit of a commercial building's OTTV be reduced from $90 \mathrm{~W} / \mathrm{m}^{2}$ to $45 \mathrm{~W} / \mathrm{m}^{2}$. Further reductions may be possible with a more secure economic future. It is also recommended that the set point temperature be increased to $27^{\circ} \mathrm{C}$.

The existing commercial buildings also could be required to adjust themselves to suit the code and the standards for existing buildings could be relaxed and easily achievable.

This exercise has been carried out for three different OTVs and their respective cooling loads. The "real" relationship of these two would be seen clearly if this experiment were conducted for a uch wider range of OTTV. Furthermore, a study on energy consumption throughout the year need to be conducted to gather the true picture of a building's energy consumption pattern. Other aspects not considered here, such as window angles, surface texture, surface color, overhang type and angle, consideration of adjoining buildings...etc. and their effect on OTTV also need to be analyzed.

The present study is merely a first attempt at providing a framework for further analysis of the EEBC with a view to improve the energy efficiency of Sri Lankan buildings. More designers and engineers are encouraged to build on this platform to create a truly energy efficient building code that will actually save energy and provide vital economic and ecological benefit to the country.

\section{References}

Ambler, H.R., (1955). "Notes on the Climate of Nigeria With Reference to Personnel", J. Tropical Medicine \& Hygiene, 58: 99-112.

Auficiems, A, (1983). Psychophysical Citteriafor Gbbal Therma Zones of Building Design", Biometeorology, 8(2):69-86. 
Ballantyne, E.R., J.R. Barned \& J.W. Spencer, (1967). "Environment Assessment of Acclimatized Caucasian Subjects at Port Morsby, Papua", Proc. Third Australian Building Research Congress.

CEB \& Department of Electrical Engineering, University of Moratuwa, (1997). Energy Efficient Lighting for Households - final report.

Code of Practice for Energy Conservation in Bullding Services, Part 2: Ventilation \& Air Conditioning Systems, Singapore Standards CP24:Part 2:1983, Singapore: Singapore Institute of Standards and Industrial Research.

Code of Practice for Overall Thermal Transfer Value in Bulldings, (1995). Hong Kong: Building Authority.

Energy Efficient Bullding Code for Commercial Buildings Code, (EEBC), (2000). Prepared for the Ceylon Electricity Board by, Lawrence Berkeley National Laboratory, Berkeley, CA, USA and Econoler Intemational, Quebec City, Quebec, Canada.

Ellis, F.P., (1952). “Thermal Comfort in Warm, Humid Atmospheres. Observations in a Warship in the Tropics", J. Hygiene, 50: 415.

- (1953). "Thermal Comfort in Warm and Humid Atmospheres. Observations on Groups and Individuals in Singapore", J. Hygiene, 51:386.

Emmanuel, R., (1999). "Trends in urban climate changes in Sri Lanka: The case of the Colombo Metropolitan region." Final Report submitted to the Senate Research Committee of the University of Moratuwa, Sri Lanka. SRC Grant No. 99/01/ 11.

Guidelines for Energy Efficiency in Buildings, (1989). Kuala Lumpur, Malaysia: Ministry of Energy, Telecommunication and Posts.

Humphreys, M.A., (1981). "The Dependence of Comfortable Temperatures on indoor and Outdoor Climates". In, Cena, K..\& J.A. Clark, (eds.), Bioengineering, Thermal Physiology \& Comfort, Amsterdam: Elsevier, pp. 229-250.

Nicol, J.F., (1974). "An Analysis of Some Observations of Thermal Comfort in Roorkee, India, and Baghdad, Iraq", Annals of Human Biology, 1(4): 411-426.

Prins, G., (1992). "On Condis \& Coolth", Energy \& Buildings, 18: 251-258.

Rao, M.N., (1952). "Comfort Range in Tropical Calcutta. A preliminary Experiment", Indian J. Medical Research, 40: 45

Rivera de Figueroa, C.A., (1980). Architecture for the Tropics: A Bibliographical Synthesis from the beginnings to 1972). Rio Piedras, Puerto Rico: Editorial Universitaria, University of Puerto Rico.

Rogithan, R., (2001). Applicability of the building envelope requirements of the 'Energy Efficient Building Code for Commercial Buildings in Sri Lanka', M.Sc. Dissertation, University of Moratuwa, Sri Lanka/

Webb, C.G., (1959). "An Analysis of Some Observations of Thermal Comtort in an Equatorial Climate", British J. Industrial Medicine, 16: 297.

Wyndham, C.H., (1963). "Thermal Comfort in the Hot, Humid Tropics of Australia", British J. Industrial Medicine, 20: 110. 